\title{
The effect of dietary methionine levels on growth, feed conversion and protein retention efficiency of Nile Tilapia (Oreochromis niloticus) fingerlings
}

\author{
FOUZI A. MOHAMMED”, RAMZY A. YOUSIF, FATIMA M. HILAL, RAHMA A. ADAM, TAMNY K. AHMED \\ Department of Fisheries and Wildlife Science, Sudan University of Science and Technology. P.O.Box 204, Khartoum, Sudan. \\ Tel.: +249-91212 1941, `email: fawzi122@gmail.com, fawzi@sustech.edu.sd, ramzy173@gmail.com
}

Manuscript received: 14 December 2019. Revision accepted: 15 January 2020

\begin{abstract}
Mohammed FA, Yousif RA, Hilal FM, Adam RA, Ahmed TK. 2020. The effect of dietary methionine levels on growth, feed conversion and protein retention efficiency of Nile Tilapia (Oreochromis niloticus) fingerlings. Nusantara Bioscience 12: 21-27. A 49 days feeding trial was conducted to evaluate growth, feed utilization and body composition of Nile tilapia Oreochromis niloticus

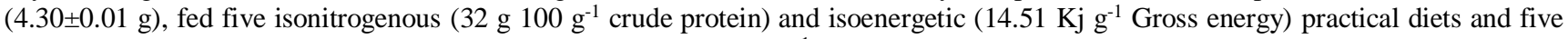

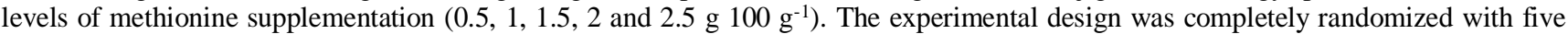
treatments and three replicates. Fish were stocked in triplicate groups of 20 fish held in $70 \mathrm{~L}$ flow-through tanks (water volume $55 \mathrm{~L}$ ) and fed twice daily (08:00 am and 04:30 pm) to apparent satiation. When absolute weight gain (AWG; $\mathrm{g}^{\mathrm{a}} \mathrm{sh}^{-1}$ ), feed conversion ratio, protein deposition $\left(\mathrm{g} \mathrm{fish}^{-1}\right)$ and protein retention efficiency $(\%)$ data were subjected to second-degree polynomial regression analysis

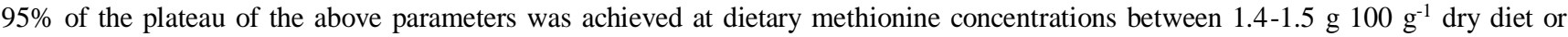


requirement for Nile tilapia Oreochromis niloticus is recommended 1.4-1.5 g $100 \mathrm{~g} \mathrm{~g}^{-1}$ diet.
\end{abstract}

Keywords: Growth performance, methionine, Oreochromis niloticus, requirement

\section{INTRODUCTION}

Tilapia is considered to be the most popular and cultivated species of aquaculture after carp. However, global tilapia aquaculture production is highly imbalanced, with the top ten countries in 2015 accounting for over 90 percent of the 5.7 million tonnes of global production (FAO 2018). Nile tilapia (Oreochromis niloticus) ranks $6^{\text {th }}$ among the most important cultured species, providing food, jobs, domestic and exporting earnings (FAO 2018). Also, it is an important protein source, especially for poor consumer because they are tolerant of high density in aquaculture and relatively disease resistant (FAO 2017). The low trophic level and the omnivorous food habits of tilapia make them a relatively inexpensive fish to feed, unlike other finfish, such as salmon, which rely on high protein and lipid diets based on more expensive protein sources like a fish meal (Jauncey 2000). In addition, tilapia are similar to channel catfish (Ictalurus punctatus), in that they can tolerate higher dietary fiber and carbohydrate concentrations than most other cultured fish. To ensure high yield and fast growth at least cost, a well-balanced prepared feed is essential to successful tilapia culture. Slight variations exist among tilapia species, but nutrient requirements are primarily affected by the size of the fish (Jauncey 2000; El-Sayed 2006; NRC 2011).

Methionine is an essential amino acid required by all animals including fish and crustaceans for protein synthesis (Ketola 1982; Teshima et al. 2003; Alam et al. 2005; Khan and Abidi 2013). It is converted to cysteine for incorporation into protein. Cysteine is a dispensable amino acid and is synthesized from methionine (Khan and Abidi 2013). Therefore, it should also be provided in the diet appropriately. Its presence in the diet at requisite level may spare some of the methionine normally required for its synthesis (Khan and Abidi 2013). Methionine is the precursor of the polyamines, spermine, and spermidine, which have diverse physiological roles related to cell proliferation and growth (Murray et al. 1996). In fish both excess and restricted dietary methionine content have been reported to affect growth performance, feed intake and carcass quality (Jackson and Capper 1982; Rumsey et al. 1983; Mambrini et al. 2001; Sveier et al. 2001).

Understanding of sulfur amino acid in the nutrition of fish is essential for substitution of animal feedstuffs with plant feedstuffs which is frequently adopted in replacement strategy for fishmeal. As plant feedstuffs are limiting in methionine, this often results in methionine deficiency causing (Alexis et al. 1985; Poston 1986; Goff and Gatlin 2004; Khan and Abidi 2013) growth retardation, reduced feed efficiency and lenticular cataracts in several salmonids species (Walton et al. 1982; Rumsey et al. 1983; Cowey et al. 1992). The complete 10 quantitative essential amino requirements have been established for only a limited number of cultured fish species (Nose 1979; Ogino 1980; Santiago and Lovell 1988; Ravi and Devaraj 1991; Arai and Ogata 1993; Borlongan and Coloso 1993; Khan and Jafri 1993; NRC 1993; Ng and Hung 1995; Abidi and Khan 2004a,b, 2008, 2010a,b; Khan and Abidi 2007). Although most of the essential amino acid requirements including the 
methionine requirement for the fingerling stage of Nile tilapia have been established (He et al. 2017). This study was, therefore, conducted to generate data on optimum methionine requirement for maximum growth, best feed conversion, protein gain, and protein retention in Nile tilapia.

\section{MATERIALS AND METHODS}

\section{Preparation of experimental diets}

In this study, firstly proximate composition of the ingredients used in fish feeds were analyzed and five isonitrogenous $(32 \% \mathrm{CP})$ and isocaloric $\left(14.51 \mathrm{kj} \mathrm{g}^{-1}\right)$ experimental diets were formulated with varying levels of

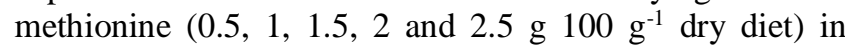
gradation of $0.5 \mathrm{~g} 100 \mathrm{~g}^{-1}$ (Table 1) and Amino acid composition of the experimental diets (Table 4). The respective dietary methionine concentrations in terms of percent protein were $1.55,3.13,4.69,6.25$, and 7.81 methionine $100 \mathrm{~g}^{-1}$ of the diet.

Crude protein content in the diet was fixed at $32 \%$ on the basis of earlier available information (Abdelghany 2000). All the ingredients were weighed and blended in a Hobart electric mixer (A-200T Mixer Bench Model unit; Ottawa, Canada) thoroughly. These were then steam cooked at $80^{\circ} \mathrm{C}$ in a volume of hot water. Oil, mineral and vitamin premixes were prepared as per Halver (2002), were added to the lukewarm bowl one by one with constant mixing at $60^{\circ} \mathrm{C}$. The final diet with bread dough consistency, and then pellets were produced by manual meat grinder with $0.6 \mathrm{~mm}$ diameter and later were dried for 24 hrs., and subsequently broken into crumbled form and each diet was packed in a plastic bag and stored until used.

\section{Experimental and feeding regime}

Fingerlings of Oreochromis niloticus were procured from Hussien Fadoul Fish Farm, Soba Agricultural Scheme Khartoum, Sudan. These fingerlings were transported to hatchery of the Department of fisheries and Wildlife Science, Sudan University of Science \& Technology, Khartoum, Sudan, in oxygen-filled polyethylene sac and stocked in fiberglass for three days in this period. After that, use of small deep net to caught fingerlings and then weight the fingerlings and standardized then transferred to medium aquarium and circular pond. During this period, the fish were fed to apparent satiation by feeding diet consisting of groundnut cake, wheat bran, and wheat middling in the form of dried powder diet twice a day at 08:00 a.m. and 04:30 p.m. For conducting the experiments, Oreochromis niloticus fingerlings $(4.30 \pm 0.01 \mathrm{~g} ; \mathrm{n}=3 \times 20)$ for experiment, were sorted out from the above-acclimated lot and stocked in triplicate groups in 70-L circular polyvinyl tanks (water volume $55 \mathrm{~L}$ ) fitted with a continuous water flow-through $\left(1-1.5 \mathrm{~L} \mathrm{~min}^{-1}\right)$ system at the rate of 20 fish per replicate for each dietary treatment. Fish were fed test diets in the form of powder diet to apparent satiation twice daily 08:00 a.m. and 04:30 p.m. No feed was offered to the fish on the day they were weighed, initial and weekly weights were recorded on a top-loading balance (Precisa 120A; $0.1 \mathrm{mg}$ sensitivity, Oerlikon AG, Zurich, Switzerland). The feeding trial lasted for 49-days. Fecal matter and unconsumed feed, if any, were siphoned off. The unconsumed feed was filtered on a screen soon after active feeding, dried, and weighed to measure the amount of feed consumed.

\section{Water quality parameters}

Water quality was sampled from each trough daily during the feeding trial were recorded following standard methods (APHA 1992). The range of water temperature, dissolved oxygen, ammonia, Nitrate, and $\mathrm{Ph}$, over the seven weeks feeding trial, based on daily measurements, were $29.21 \pm 0.52^{\circ} \mathrm{C}, 6.09 \pm 1.21 \mathrm{mg} \mathrm{L}^{-1}, 7.46 \pm 0.16 \mathrm{mg} \mathrm{L}^{-1}$, $1.43 \pm 0.38 \mathrm{mg} \mathrm{L}^{-1}$ and $7.52 \pm 0.40$ respectively Table 3 .

\section{Chemical analysis}

At the beginning of the experiment, 10 fish were euthanized at stocking and frozen $\left(<-15^{\circ} \mathrm{C}\right)$ for initial whole-body composition analysis, and at the termination of the seven-week feeding trial, all fish were counted and weighted, and 10 fish per trough were randomly selected for analysis of whole-body composition. Assessment of proximate composition of ingredients, diets, and carcass was made using standard techniques (AOAC 1995). Briefly, crude protein ( $\mathrm{N}$ x 6.25) was determined (Kejeltec Tecator TM Technology 2300, Sweden), dry matter was determined after drying in an oven at $105^{\circ} \mathrm{C}$, ash content was determined by incineration in a muffle furnace at 550 ${ }^{\circ} \mathrm{C}$ for $8 \mathrm{hrs}$., crude fat (solvent extraction with petroleum ether B.P. $40-60^{\circ} \mathrm{C}$ for $2-4 \mathrm{~h}$ Socs Plus, SCS 4, Pelican Equipment, Chennai, India).

\section{Growth parameters}

Growth performance of Oreochromis niloticus fed graded levels of methionine was measured as a function of the weight gain by calculating following parameters:

Absolute weight gain $\left(\mathrm{g}\right.$ fish $\left.^{-1}\right)=$ Final individual body weight-Initial individual body weight.

Live weight gain $(\mathrm{LWG} ; \%)=$ Final individual body weightInitial individual bodyweight/Initial individual bodyweight $\times 100$.

Feed conversion ratio $(\mathrm{FCR})=$ Dry feed fed/Wet weight gain

Protein efficiency ratio $(\mathrm{PER})=$ Weight gain/Protein fed.

Protein Retention Efficiency $=($ Final bodyweight $\mathrm{x}$ Final protein)-(Initial bodyweight $x$ Initial protein)/ Initial Protein $\times 100$.

Specific growth rate $\left(\mathrm{SGR} ; \%\right.$ day $\left.^{-1}\right)=\mathrm{Ln}$ Final body weightLn Initial body weight/No. of days $\times 100$.

Protein gain $\left(\mathrm{g}_{\text {fish }}{ }^{-1}\right)=$ final body weight $\mathrm{X}$ final body protein - initial body weight $\mathrm{X}$ initial body protein/protein fed.

Survival $(\mathrm{SR} ; \%)=($ Final number of fish/Initial number of fish) $\times 100$. 
Table 1. Composition of experimental diets

\begin{tabular}{|c|c|c|c|c|c|}
\hline \multirow{2}{*}{$\begin{array}{c}\text { Ingredients } \\
\text { (g/ } 100 \text { g dry diet) }\end{array}$} & \multicolumn{5}{|c|}{ Diets } \\
\hline & (D1)0.5 & (D2)1 & (D3) 1.5 & (D4)2 & (D5) 2.5 \\
\hline Fish meal $^{1}$ & 40.0 & 40.0 & 40.0 & 40.0 & 40.0 \\
\hline Sorghum meal $^{2}$ & 10.0 & 10.0 & 10.0 & 10.0 & 10.0 \\
\hline Groundnut Cake ${ }^{3}$ & 14.0 & 14.0 & 14.0 & 14.0 & 14.0 \\
\hline Cornmeal flour $^{4}$ & 5.0 & 5.0 & 5.0 & 5.0 & 5.0 \\
\hline Wheat bran ${ }^{5}$ & 10.0 & 10.0 & 10.0 & 10.0 & 10.0 \\
\hline Wheat middling ${ }^{6}$ & 9.0 & 9.0 & 9.0 & 9.0 & 9.0 \\
\hline Vig-Oil $^{7}$ & 6.0 & 6.0 & 6.0 & 6.0 & 6.0 \\
\hline Mineral premix ${ }^{8}$ & 1.5 & 1.5 & 1.5 & 1.5 & 1.5 \\
\hline Vitamin premix ${ }^{9}$ & 1.5 & 1.5 & 1.5 & 1.5 & 1.5 \\
\hline Methionine & 0.5 & 1.0 & 1.5 & 2.0 & 2.5 \\
\hline$\alpha$-Cellulose & 2.5 & 2.0 & 1.5 & 1.0 & 0.5 \\
\hline Total & 100.0 & 100.0 & 100.0 & 100.0 & 100.0 \\
\hline Protein C.P (\%) & $32.0 \pm 0.3$ & $32.0 \pm 0.03$ & $32.0 \pm 0.2$ & $32.0 \pm 0.03$ & $32.0 \pm 0.03$ \\
\hline E.E\% & $3.6 \pm 0.07$ & $3.8 \pm 0.07$ & $3.5 \pm 0.21$ & $3.6 \pm 0.07$ & $3.5 \pm 0.07$ \\
\hline Ash\% & $12.0 \pm 0.0$ & $13.5 \pm 0.71$ & $11.5 \pm 0.71$ & $13.5 \pm 0.71$ & $13.5 \pm 0.71$ \\
\hline Calculated gross energy $\left(\mathrm{kJ} \mathrm{g}^{-1}\right.$, dry diet $)$ & $14.51 \pm 0.1$ & $14.51 \pm 0.1$ & $14.51 \pm 0.1$ & $14.51 \pm 0.1$ & $14.51 \pm 0.1$ \\
\hline
\end{tabular}

Note: 1Fishmeal 54\% CP; 2Sorghum meal 10\%; 3Groundnut Cake 43.3\% CP; 4Cornmeal flour 9, 5Wheat bran 13.7\%; 6Wheat Middling 17\% CP, 7Vigetable oil (sunflower oil) and 8Mineral mixture (g/100g dry diet) calcium biphosphate 13.57; calcium lactate 32.69; ferric citrate 02.97; magnesium sulphate 13.20; potassium phosphate (dibasic) 23.98; sodium biphosphate 08.72; sodium chloride 04.35; almunium chloride. $6 \mathrm{H} 2 \mathrm{O} 0.0154$; potassium iodide 0.015 ; cuprous chloride 0.010 ; mangnous sulphate $\mathrm{H} 20$ 0.080; cobalt chloride. $6 \mathrm{H} 2 \mathrm{O} 0.100$; zinc sulphate. $7 \mathrm{H} 2 \mathrm{O} 0.40$ (Halver 2002). 9Vitamin mixture (g/100 dry diet) choline chloride 0.500 ;inositol 0.200 ; ascorbic acid 0.100; niacin 0.075; calcium pantothenate 0.05 ; riboflavin 0.02 ; menadione 0.004 ; pyridoxine hydrochloride 0.005 ; thiamin hydrochloride 0.005; folic acid 0.0015; biotin 0.0005; alpha-tocopherol 0.04; vitamin B12 0.00001; LobaChemie, India (Halver 2002)

\section{Statistical analyses}

A completely randomized design with three replicates per treatment was used for assessing the methionine requirement of the Nile tilapia fingerlings. All growth data were subjected to analysis of variance (Snedecor and Cochran 1968; Sokal and Rohlf 1981). The response variables were subjected to polynomial regression analysis $\left(\mathrm{Y}=\mathrm{a} \mathrm{X}^{2}+\mathrm{bX}+\mathrm{c}\right.$; where $\mathrm{y}=$ response variable; $\mathrm{a}=$ intercept; $b=$ coefficient of the linear terms; $c=$ coefficient of quadratic terms; $\mathrm{x}=$ dietary methionine concentrations; Zeitoun et al. 1976). Dietary methionine requirement for maximum growth, feed conversion, protein gain, and PRE is taken as the point on the abscissa representing $95 \%$ of the value of the upper asymptote on the ordinate (Dias et al. 2003). All data were analyzed statistically using SPSS (version 21; SPSS Software) and ORIGIN (version 6.0; Origin Software, San Clemente, CA, USA).

\section{RESULTS AND DISCUSSION}

\section{Growth performance}

The effects of dietary L-methionine levels on growth, feed conversion, protein gain PD, and PRE of Oreochromis niloticus are depicted in Table 2. The AWG $\mathrm{g}$ fish $^{-1}$, FCR, PD g fish ${ }^{-1}$, and PRE\% were plotted against varying levels of dietary methionine concentrations. The methionine requirement was determined by fitting the above doseresponse data to polynomial regression analyses. $\mathrm{Y}_{95 \% \max }$ was found to be considerably different in response to dietary methionine concentrations for all the response criteria. The $95 \% \mathrm{Y}_{\max }$ of AWG as a function of dietary methionine levels $\left(\mathrm{X}_{95 \% \mathrm{max}}\right)$ for using the polynomial model, the dietary methionine requirement for $95 \%$ of maximum gain in absolute weight (AWG g per fish) was

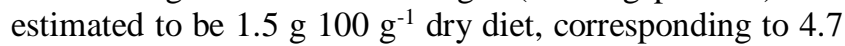
g $100 \mathrm{~g}^{-1}$ dietary protein (Figure 1). Using weight gain as response criteria, quadratic polynomial regression can be best described the methionine requirement $(100 \mathrm{~g}-1)$ at different levels and equations as follows:

\section{$\mathrm{Y}=1.778 \mathrm{X}^{2}-0.567 \mathrm{X}+1.15 \mathrm{R}^{2}=0.81$}

Polynomial regression of FCR data $\left(\mathrm{Y}_{95 \% \max }\right)$ against dietary methionine concentrations (X), exhibited best FCR to be at $1.5 \mathrm{~g}$ methionine $100 \mathrm{~g}^{-1}$ dry diet, corresponding to


PRE\% data $\left(\mathrm{Y}_{95 \% \max }\right)$ to dietary concentrations of methionine (X) was fitted by polynomial regression analysis. The curve attained its $95 \%$ maximum response at $48.36 \%$ of PRE that corresponded to an optimum dietary


dry diet corresponding to $4.7 \mathrm{~g}_{100 \mathrm{~g}^{-1}}$ dietary protein (Figure 3). Polynomial regression analysis at 95\% maximum response of AWG $\mathrm{g}$ fish ${ }^{-1}$, FCR, PD $\mathrm{g}$ fish ${ }^{-1}$, and PRE\% data depicted that these response variables were best attained at a dietary methionine in the range of 1.4-1.5 g

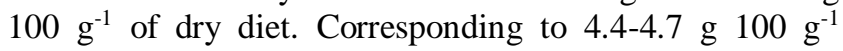
dietary protein. The economic evaluation the outcome in Table 5 showed that the costs of experimental diets based on the diet substances in the local market during the experiment, the diet substances, price (Sudanese Currency/kg), handlings, food conversion ratio and the total price (Sudanese currency/kg). 
Table 2. Growth, survival and feed utilization of Nile tilapia fed experimental diets

\begin{tabular}{|c|c|c|c|c|c|c|}
\hline & \multicolumn{5}{|c|}{ Dietary methionine levels (\% dry diet) } & \multirow{2}{*}{ Sig } \\
\hline & (D1) 0.5 & (D2) 1 & (D3) 1.5 & (D4) 2 & (D5) 2.5 & \\
\hline IW (g) & $4.31 \pm 0.01$ & $4.30 \pm 0.05$ & $4.30 \pm 0.02$ & $4.31 \pm 0.01$ & $4.30 \pm 0.01$ & - \\
\hline $\mathrm{FW}(\mathrm{g})$ & $6.35 \pm 0.01 b$ & $6.42 \pm 0.03 \mathrm{a}$ & $6.68 \pm 0.10 \mathrm{a}$ & $5.60 \pm 0.03 \mathrm{c}$ & $5.40 \pm 0.03 c$ & $*$ \\
\hline AWG (g fish-1) & $2.04 \pm 0.01 b$ & $2.12 \pm 0.38 \mathrm{a}$ & $2.38 \pm 0.23 \mathrm{a}$ & $1.29 \pm 0.24 c$ & $1.10 \pm 0.21 \mathrm{c}$ & $*$ \\
\hline LWG \% & $47.33 \pm 1.37 b$ & $49.30 \pm 1.55 b$ & $55.35 \pm 1.41 \mathrm{a}$ & $29.93 \pm 4.73 d$ & $25.58 \pm 2.60 \mathrm{c}$ & $* *$ \\
\hline $\operatorname{SGR}(\% /$ day $)$ & $0.86 \pm 0.01 b$ & $0.89 \pm 0.01 b$ & $0.98 \pm 0.02 \mathrm{a}$ & $0.58 \pm 0.01 \mathrm{c}$ & $0.51 \pm 0.01 \mathrm{c}$ & $*$ \\
\hline FCR & $2.06 \pm 0.07 b$ & $1.98 \pm 0.11 \mathrm{c}$ & $1.76 \pm 0.06 c$ & $3.26 \pm 0.04 a$ & $3.82 \pm 0.03 \mathrm{a}$ & $*$ \\
\hline PER & $1.62 \pm 0.01$ & $1.68 \pm 0.01$ & $1.89 \pm 0.03$ & $1.02 \pm 0.01$ & $0.87 \pm 0.01 \mathrm{a}$ & - \\
\hline PRE $(\%)$ & $45.01 \pm 0.2 b$ & $45.31 \pm 0.4 b$ & $48.36 \pm 0.2 \mathrm{a}$ & $27.89 \pm 0.35 c$ & $25.49 \pm 0.3 c$ & $*$ \\
\hline PG ( $\mathrm{g}$ fish-1) & $0.56 \pm 0.01$ & $0.57 \pm 0.01$ & $0.61 \pm 0.02$ & $0.35 \pm 0.01$ & $0.32 \pm 0.01$ & - \\
\hline Survival \% & $100 \mathrm{a}$ & $100 \mathrm{a}$ & $100 \mathrm{a}$ & $98 b$ & $98 b$ & $*$ \\
\hline
\end{tabular}

Note: Mean values of the three replicates $(\mathrm{n}=3 \times 20)$, Means in the same row with the same letter are not remarkably different $(\mathrm{P}>0.05)$.

Table 3. Mean physical-chemical parameters of the test concentrations feed on water quality diets

\begin{tabular}{|c|c|c|c|c|c|c|}
\hline \multirow{2}{*}{ Parameters } & \multicolumn{5}{|c|}{ Dietary methionine levels (\% dry diet) } & \multirow{2}{*}{ Sig } \\
\hline & (D1) 0.5 & (D2) 1 & (D3) 1.5 & (D4) 2 & (D5) 2.5 & \\
\hline $\mathrm{pH}$ & $7.7 \pm 0.34 \mathrm{a}$ & $7.7 \pm 0.50 \mathrm{a}$ & $7.3 \pm 0.47 b$ & $7.7 \pm 0.35 a$ & $7.2 \pm 0.35 c$ & $*$ \\
\hline NH3 & $7.22+0.12$ & $7.43+0.19$ & $7.40+0.13$ & $7.60+0.19$ & $7.65+0.19$ & - \\
\hline $\mathrm{NO} 2$ & $0.01+0.00$ & $0.00+0.00$ & $0.00+0.00$ & $0.01+0.00$ & $0.01+0.00$ & - \\
\hline NO3 & $2.6 \pm 0.01 \mathrm{a}$ & $1.57 \pm 1.86 b$ & $1.63 \pm 0.00 \mathrm{~b}$ & $0.13 \pm 0.00 \mathrm{c}$ & $1.20 \pm 0.02 \mathrm{~b}$ & $*$ \\
\hline DO & $5.55 \pm 0.29$ & $5.68 \pm 0.33$ & $5.72 \pm 1.63$ & $7.30 \pm 1.90 \mathrm{a}$ & $6.22 \pm 1.90 b$ & $*$ \\
\hline Temperature & $29.60+0.50 a$ & $29.40+0.51 \mathrm{a}$ & $29.60+0.53 a$ & $28.23+0.51 b$ & $29.23+0.51 \mathrm{a}$ & $*$ \\
\hline
\end{tabular}

Note: ${ }^{a, b, c}$ Mean values followed by the same superscript in each row are not significantly different $(\mathrm{p}>0.05)$

Table 4. Amino acid composition (\% dry matter) of the experimental diets. Calculated based on the plant feedstuff values reported for Nile tilapia (Furuya et al. 2010; NRC 2011)

\begin{tabular}{llllll}
\hline & \multicolumn{5}{c}{ Experimental diets } \\
\cline { 2 - 6 } & (D1) 0.5 & (D2) 1 & (D3) 1.5 & (D4) 2 & (D5) 2.5 \\
\hline Arginine, \% & 3.60 & 3.60 & 3.60 & 3.60 & 3.60 \\
Histidine, \% & 1.28 & 1.28 & 1.28 & 1.28 & 1.28 \\
Isoleucine \% & 1.88 & 1.88 & 1.88 & 1.88 & 1.88 \\
Leucine \% & 3.32 & 3.32 & 3.32 & 3.32 & 3.32 \\
Lysine \% & 3.21 & 3.21 & 3.21 & 3.21 & 3.21 \\
Cystine \% & 0.11 & 0.11 & 0.11 & 0.11 & 0.11 \\
Phenylalanine \% & 2.03 & 2.03 & 2.03 & 2.03 & 2.03 \\
Tyrosine \% & 1.81 & 1.81 & 1.81 & 1.81 & 1.81 \\
Threonine \% & 1.89 & 1.89 & 1.89 & 1.89 & 1.89 \\
Tryptophan \% & 0.09 & 0.09 & 0.09 & 0.09 & 0.09 \\
Valine \% & 2.34 & 2.34 & 2.34 & 2.34 & 2.34 \\
Methionine \% & 1.80 & 2.30 & 2.80 & 3.30 & 3.80 \\
\hline
\end{tabular}

Table 5. The economic evaluation of the experimental diets/Sudanese currency (SDG)

\begin{tabular}{|c|c|c|c|c|c|c|c|c|}
\hline \multirow{2}{*}{$\begin{array}{c}\text { Ingredients (g/ } 100 \text { g dry } \\
\text { diet) }\end{array}$} & \multirow{2}{*}{$\begin{array}{c}\text { CP-Ing. } \\
(\%)\end{array}$} & \multirow{2}{*}{$\begin{array}{l}\% \text { Contribution of } \\
\text { ing. (Protein) }\end{array}$} & \multirow{2}{*}{$\begin{array}{c}\text { Price } \\
\text { (SDG/kg) }\end{array}$} & \multicolumn{5}{|c|}{ Total price SDG } \\
\hline & & & & (D1)0.5 & (D2)1 & (D3)1.5 & (D4)2 & (D5)2.5 \\
\hline Fish meal $^{1}$ & 54 & 21.60 & 100 & 40.00 & 40.00 & 40.00 & 40.00 & 40.00 \\
\hline Sorghum meal $^{2}$ & 10 & 1.00 & 32 & 3.20 & 3.20 & 3.20 & 3.20 & 3.20 \\
\hline Groundnut cake ${ }^{3}$ & 43,3 & 6.06 & 50 & 7.00 & 7.00 & 7.00 & 7.00 & 7.00 \\
\hline Cornmeal flour ${ }^{4}$ & 9 & 0.45 & 70 & 3.50 & 3.50 & 3.50 & 3.50 & 3.50 \\
\hline Wheat bran ${ }^{5}$ & 13,7 & 1.37 & 17 & 1.70 & 1.70 & 1.70 & 1.70 & 1.70 \\
\hline Wheat middling ${ }^{6}$ & 17 & 1.53 & 20 & 1.80 & 1.80 & 1.80 & 1.80 & 1.80 \\
\hline Vig-Oil $^{7}$ & 0 & 0.00 & 35 & 2.10 & 2.10 & 2.10 & 2.10 & 2.10 \\
\hline Mineral premix ${ }^{8}$ & 0 & 0.00 & 60 & 0.90 & 0.90 & 0.90 & 0.90 & 0.90 \\
\hline Vitamin premix ${ }^{9}$ & 0 & 0.00 & 60 & 0.90 & 0.90 & 0.90 & 0.90 & 0.90 \\
\hline Methionine & 0 & 0.00 & 100 & 0.50 & 1.00 & 1.50 & 2.00 & 2.50 \\
\hline$\alpha$-Cellulose & 0 & 0.00 & 80 & 2.00 & 1.60 & 1.20 & 0.80 & 0.40 \\
\hline Total & & 32.0 & & 63.6 & 63.7 & 63.8 & 63.9 & 64.0 \\
\hline FCR & & & & 2.06 & 1.98 & 1.76 & 3.26 & 3.82 \\
\hline
\end{tabular}




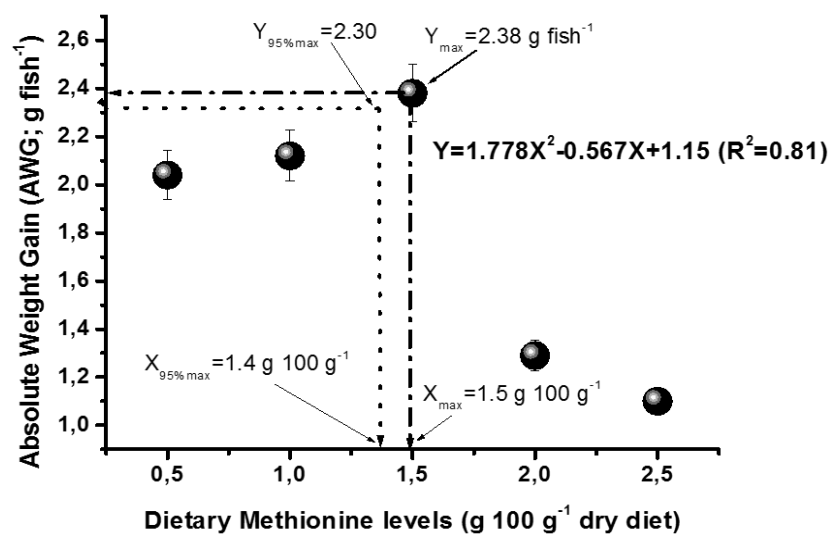

Figure 1. Second-degree polynomial relationship of absolute weight gain (AWG; g/fish) to dietary methionine level

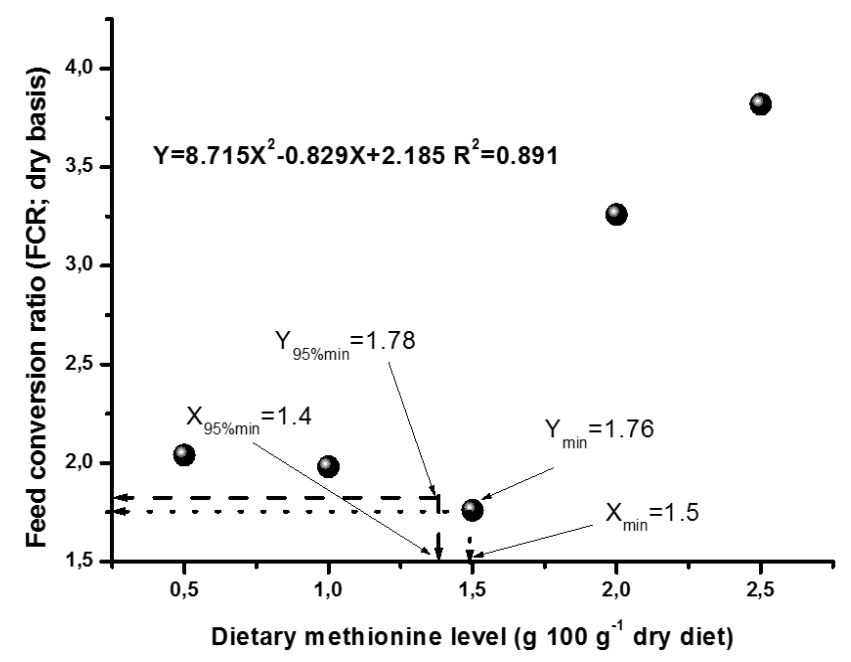

Figure 2. Second-degree polynomial relationship of feed conversion ratio (FCR) to dietary methionine level

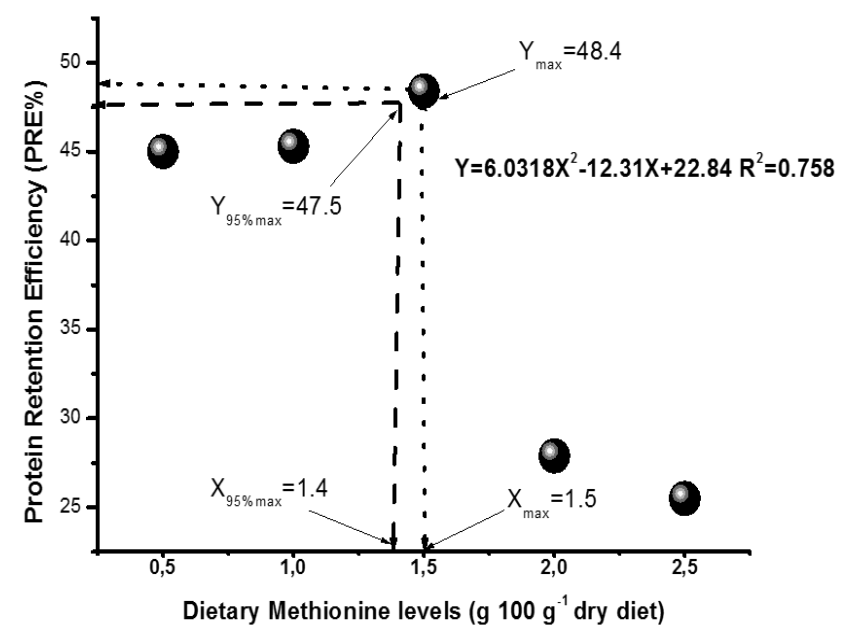

Figure 3. Second-degree polynomial relationship of protein retention efficiency (PRE \%) to dietary methionine level



Figure 4. Second-degree polynomial relationship of protein deposition (PD; g/fish) to dietary methionine level

\section{Discussion}

Growth performance, feed conversion ratio (FCR), protein gain, $\mathrm{PD}$, and protein retention efficiency PRE in Oreochromis niloticus was found to improve with the


study. On subjecting the response variables to polynomial regression analyses, 95\% maximum response in terms of AWG g fish-1, FCR, PD $g$ fish $^{-1}$, and PRE\% occurred at the dietary methionine concentrations between 1.4 and 1.5 $\mathrm{g} 100 \mathrm{~g}^{-1}$ diet. Methionine is used for a variety of functions in addition to protein synthesis (Finkelstein 1990). Also, the obligatory oxidation rate for methionine is greater than that for lysine (Yamashita and Ashida 1969; Aguilar et al. 1972; Garlick et al. 1976; Khan and Abidi 2013; Yousif et al. 2019a,b). These values in the present study were similar to the results of He et al. 2017, Santiago and Lovell (1988), and Liebert and Benkendorff (2007) and Liebert (2009), in Nile tilapia, while and in T. zillii tilapia (Polat 1999), Mozambique tilapia (Jackson and Capper 1982), hybrid tilapia Oreochromis niloticus x O. aureus (Lin et al. 2008) and Nile tilapia (Michelato et al. 2013; Nguyen and Davis 2009).

Choice of mathematical models in estimating the dietary level for a limiting nutrient is very important. In this study using nonlinear regression analysis (seconddegree polynomial regression analysis) at a confidence interval of $95 \%$ have been employed for the determination of the methionine requirement of Oreochromis niloticus. The model resulted in extremely high coefficients of determination $\left(\mathrm{R}^{2}\right)$ indicating that the polynomial model was a good fit for the data during this study. Therefore, the methionine requirement determined has been recommended in the range for Nile tilapia.

The PD data $\left(\mathrm{Y}_{95 \% \max }\right)$ to dietary concentrations of methionine $(\mathrm{X})$ was fitted by polynomial regression analysis. The curve attained its $95 \%$ maximum response at 0.61 of PD that corresponded to an optimum dietary methionine

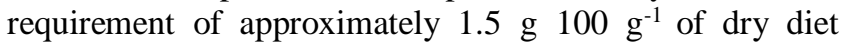

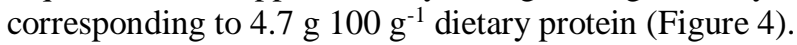


Table 6. Whole-body chemical analysis of Nile tilapia Oreochromis niloticus fingerlings fed graded levels of Methionine

\begin{tabular}{|c|c|c|c|c|c|c|c|}
\hline \multicolumn{8}{|c|}{ Experimental diets } \\
\hline \% we weight & Initial & (D1) 0.5 & (D2) 1 & (D3) 1.5 & (D4) 2 & (D5) 2.5 & Sig \\
\hline Moisture & $79.50 \pm 0.71$ & $76.50 \pm 0.71^{\mathrm{a}}$ & $75.0 \pm 0.00^{\mathrm{b}}$ & $75.0 \pm 4.24^{\mathrm{b}}$ & $75.0 \pm 2.83^{b}$ & $74.0 \pm 2.83^{\mathrm{c}}$ & $*$ \\
\hline $\mathrm{CP}$ & $12.27 \pm 0.01$ & $17.02 \pm 0.01^{\mathrm{a}}$ & $17.11 \pm 0.02^{\mathrm{a}}$ & $17.26 \pm 0.01^{\mathrm{a}}$ & $15.72 \pm 0.02$ & $15.72 \pm 0.02$ & $*$ \\
\hline Fat & $3.10 \pm 0.04$ & $3.17 \pm 0.02$ & $3.22 \pm 0.01$ & $3.85 \pm 0.02$ & $4.01 \pm 0.04^{\mathrm{a}}$ & $4.12 \pm 0.03^{\mathrm{a}}$ & $*$ \\
\hline Ash & $3.70 \pm 0.01$ & $3.81 \pm 0.2$ & $3.78 \pm 0.01$ & $3.52 \pm 0.02$ & $3.40 \pm 0.02$ & $3.30 \pm 0.10$ & - \\
\hline
\end{tabular}

In this study, PRE showed higher percent at 1.5 methionine diet it was $48.4 \%$. It is well known that amino acid deficiencies and imbalances decrease protein retention. Fish fed dietary methionine at $0.5,2$ and $2.5 \mathrm{~g}$ $100 \mathrm{~g}^{-1}$ showed appreciably less protein retention. This result, similar to the results of (Khan and Abidi 2013) $\mathrm{NRE}$ in fish fed at $1.7 \mathrm{~g}$ methionine $100 \mathrm{~g}^{-1}$ of the diet indicates to more efficient utilization of individual amino acids at this level. It has also been reported that excessive levels of amino acids may become toxic and may have adverse effect on growth, because the disproportionate intake affects the absorption and utilization of other amino acids or decrease the diet's palatability (Harper et al. 1970; Borlongan and Coloso 1993; Murthy and Varghese 1996; Murthy and Varghese 1998).

The results of whole-body content or the carcass composition very important for nutritional value of Nile tilapia. In table 4. moisture in the experiment ranged from 74.0 to $76.0 \%$. The fat in body ranged between 3.1 to $4.12 \%$. Crude protein in body of fish in D4\&5 is $(15.72 \%$

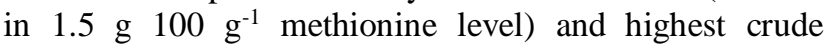

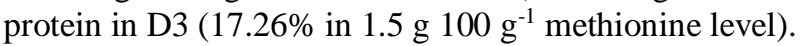

Based on the second-degree polynomial regression analyses of $95 \%$ maximum response in terms of AWG, FCR, protein gain, and PRE data, diets of Nile tilapia fingerlings Oreochromis niloticus should contain


maximize growth, feed conversion, and protein retention. However, the information generated during this study is useful in designing methionine balanced feeds for mass rearing of Nile tilapia fingerlings.

In conclusion, the experiment showed that feeds were actively consumed by the experimental fish, Nile tilapia which brought an increase in weight. Since there was no significant difference $(P>0.05)$ among the means of the treatments, it shows that any of the inclusion levels can be

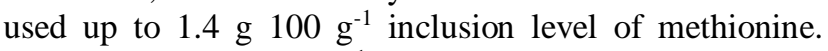

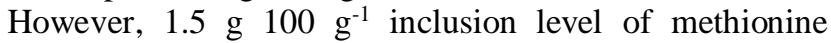
produced best result in terms of growth, PD, and PRE\%. It is therefore recommended that methionine can be

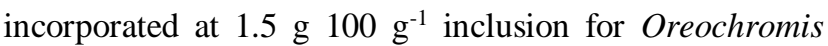
niloticus without compromising fish growth.

\section{ACKNOWLEDGEMENTS}

The authors are grateful to the Dean, College of Animal Production Science and Technology and the head department of Fisheries and Wildlife Science, Sudan
University of Science \& Technology for providing necessary laboratory facilities and also the assistance rendered by Hussien Fadoul Fish hatchery (Soba Agriculture Scheme-Sudan) for providing us the Nile Tilapia and also technical staff Department of Fisheries and Wildlife Science for their assistance in laboratory work namely: Mr. Ahmed Babay and Ms. Abeer Musa.

\section{REFERENCES}

Abdelghany AE. 2000. Optimum dietary protein requirements for Oreochromis niloticus L. fry using formulated semi-purified diet. In: Fitzsimmons K, Filho JC. (eds.). Tilapia Aquaculture in $21 \mathrm{st}$ Century. Proc.from the 5th Intl. Symp.on Tilapia in aquaculture. Rio de Janeiro, Brazil, 3-7 September 2000.

Abidi SF, Khan MA. 2004a. Dietary valine requirement of Indian major carp, Labeo rohita (Hamilton). J Appl Ichthyol 20: 118-122.

Abidi SF, Khan MA. 2004b. Dietary histidine requirement of Indian major carp, Labeo rohita (Hamilton). Isr J Aquac-Bamidgeh 56: 200-208.

Abidi SF and Khan MA. 2007. Dietary leucine requirement of fingerling Indian major carp, Labeo rohita (Hamilton). Aquac Res 38: 478-486.

Abidi SF and Khan MA 2008. Dietary threonine requirement of fingerling Indian major carp, Labeo rohita (Hamilton). Aquac Res 39: 1498-1505.

Abidi SF and Khan MA. 2010a. Dietary tryptophan requirement of fingerling Indian major carp, Labeo rohita (Hamilton). J World Aquac Soc 41: 700-709.

Abidi SF and Khan MA. 2010b. Effects of dietary lysine levels on growth and body composition of fingerling Indian major carp, Labeo rohita (Hamilton). J World Aquac Soc 41: 791-799.

Abidi SF and Khan MA. 2013. Dietary methionine requirement of Indian major carp fry, Cirrhinus mrigala (Hamilton) based on growth, feed conversion and nitrogen retention efficiency. Aquacult Res 44: 268281.

Aguilar TS, Harper AE, Benevenga NJ. 1972. Efficiency of utilization of indispensable amino acids for growth by the rat. J Nutr 102: 11991208 .

Alam MS, Teshima S, Koshio S, Yokoyama S, Ishikawa M. 2003. Optimum dietary threonine level for juvenile Japanese flounder Paralichthys olivaceus. Asian Fish Sci 16: 175-184.

Alam MS, Teshima S, Koshio S, Ishikawa M, Uyan O, Hernandez L, Michael F. 2005. Supplemental effects of coated methionine and /or lysine to soy protein isolate diet for juvenile kuruma shrimp, Marsupenaeus japonicus. Aquaculture 248: 13-19.

Alexis MN, Papoutsoglou EP, Theochari V. 1985. Formulation of practical diets for rainbow trout (Salmon gairdneri) made by partial or complete substitution of fishmeal by poultry byproducts and certain plant byproducts. Aquaculture 50: 61-73.

AOAC 1995. Official Methods of Analysis. 16th ed. Association of Official Analytical Chemists, Arlington, VA.

APHA 1992. Standard Methods for the Examination of Water and Wastewater (18th ed). APHA, Washington, DC.

Arai S, Ogata H. 1993. Quantitative amino acid requirements of fingerling coho salmon. In: Collie MR, McVey JP (eds.). Proceedings of the Twentieth US-Japan Symposium on Aquaculture Nutrition. UJNR Department of Commerce, Newport, OR. 
Borlongan IG, Coloso RM. 1993. Requirements of juvenile milkfish (Chanos chanos Forsskal) for essential amino acids. J Nutr 123: 125132.

Cowey CB, Cho CY, Sivak JG, Weerheim JA, Stuart DD. 1992. Methionine intake in rainbow trout (Oncorhynchus mykiss), relationship to cataract formation and the metabolism of methionine. J Nutr 122: 1154-1163.

Dias MG, Sanchez MV, Bartolo H, Oliveira L. 2003. Vitamin content of fish and fish products consumed in Portugal. Electron $\mathrm{J}$ Environ, Agric and Food Chem 2 (4): 510-513.

El-Sayed AM. 2006. Tilapia culture in saltwater: Environmental requirements, nutritional implications and economic potentials. Eighth Symposium on Advances in Nutritional Aquaculture. Nuevo Leon, Mexico, 15-17 November 2006.

FAO [Food and Agriculture Organization of the United Nations]. 2017. Tilapia Lake Virus (TiLV) Caused by an Orthomyxo-like virus (Family Orthomyxoviridae) Threatening Cultured and Wild Stocks of Tilapia. September- Newsletter No. 57. FAO, Rome.

FAO [Food and Agriculture Organization of the United Nations]. 2018. Notes from the Aquaculture Statistician. Research 31, 195-205. FAO, Rome.

Finkelstein JD. 1990. Methionine metabolism in mammals. J Nutr Biochem 1: 228-237.

Furuya WM, Pezzato LE, Barros MM, Boscolo WR, Cyrino JEP, Furuya VRB, Feiden A. 2010. Tabelas brasileiras para a nutrição de tilápias. GFM, Toledo.

Garlick PJ, Burk TL, Swick RW. 1976. Protein synthesis and RNA in tissues of the pig. Am J Physiol 230: 1108-1112.

Goff JB, Gatlin DM. 2004. Evaluation of different sulfur amino acid compounds in the diet of red drum, Sciaenops ocellatus, and sparing value of cystine for methionine. Aquaculture 241: 465-477.

Halver JE. 2002. The vitamins. In: Halver JE, Hardy RW. Fish Nutrition. 3rd ed. Academic Press, San Diego, CA.

Harper AE, Benevenga NJ, Wohlhueter RM. 1970. Effects of ingestion of disproportionate amounts of amino acids. Physiol Rev 50: 428458.

He JY, Tian LX, Lemme A, Figueiredo-Silva C, Gao W, Yang HJ, Han B, Zeng SL, Liu YJ. 2017. The effect of dietary methionine concentrations on growth performance of juvenile Nile tilapia (Oreochromis niloticus) fed diets with two different digestible energy levels. Aquac Nutr 23: 76-89. Doi:10.111/anu.12362.

Jackson AJ, Capper BS. 1982. Investigation into the requirements of the tilapia Sarotherodon mossambicus for dietary methionine, lysine and arginine in semisynthetic diets. Aquaculture 29: 289-297.

Jauncey K. 2000. Nutritional requirements. P. 327-375. In: Beveridge MCM, McAndrew BJ. (eds.). Tilapias: Biology and Exploitation, Fish and Fisheries Series 25. Kluwer Academic Publishers, Dordrecht, The Netherlands.

Ketola HG. 1982. Amino acid nutrition of fish: requirement and supplementation of diets. Comp Biochem and Physiol 73B: 17-24

Khan MA, Abidi SF. 2007a. Total aromatic amino acid requirement of Indian major carp, Labeo rohita (Hamilton) fry. Aquaculture 267: 111-118

Khan MA, Abidi SF. 2007b. Dietary isoleucine requirement of fingerling Indian major carp, Labeo rohita (Hamilton). Aquacult Nutr 13: 424430.

Khan MA, Jafri AK. 1993. Quantitative dietary requirement for some indispensable amino acids in the Indian major carp, Labeo rohita (Hamilton) fingerling. J Aquacult Trop 8: 67-80.

Liebert F. 2009. Amino acid requirement studies in Oreochromis niloticus with application of principles of the diet dilution technique. J Anim Physiol Anim Nutr 93: 787-793.

Liebert F, Benkendorff K. 2007. Modelling of threonine and methionine requirements of Oreochromis niloticus due to principles of the diet dilution technique. Aquacult Nutr 13: 397-406.

Lin SM, Mai KS, Tan BP. 2008. Effect of crystalline methionine supplementation on growth performance and body composition in hybrid tilapia, Oreochromis niloticus 9 O. aureus. Acta Hydrobiol Sin 32: 741-749.

Mambrini M, Roem AJ, Crave`di JP, Lalle`s JP, Kaushik SJ. 2001. Effects of replacing fish meal with soy protein concentrate and of dl- methionine supplementation in high-energy extruded diets on the growth and nutrient utilization of rainbow trout, Oncorhynchus mykiss. J Anim Sci 77: 2990-2999.

Michelato M, Furuya WM, Graciano TS, Vidal LVO, Xavier TO, Moura LBD, Furuya VRB. 2013. Digestible methionine + cysteine requirement for Nile Tilapia from 550 to $700 \mathrm{~g}$. Revista Brasileira de Zootecnia 42: 7-12.

Murray RK, Granner DK, Mayes PA, Rodwell VW. 1996. Harper's Biochemistry (24th ed). Appleton and Lange, Stamford, CT.

Murthy HS, Varghese TJ. 1996. Quantitative dietary requirement of threonine for the growth of thee Indian major carp, Labeo rohita (Hamilton). J Aquacult Trop 11: 1-7.

Murthy HS, Varghese TJ. 1998. Total sulfur amino acid requirement of the Indian major carp, Labeo rohita (Hamilton). Aquacult Nutr 4: 61-65.

Nguyen TN, Davis DA. 2009. Methionine requirement in practical diets for juvenile Nile tilapia, Oreochromis niloticus. J World Aquacult Soc 40: 410-416.

$\mathrm{Ng}$ WK, Hung SSO. 1995. Estimating the ideal dietary essential amino acid pattern or growth of white sturgeon, Acipensor transmontanus (Richardson). Aquacult Nutr 1: 85-94.

Nose T. 1979. Summary report on the requirements of essential amino acids for carp. In: Halver JE, Tiews K (eds.). Finfish Nutrition and Fish feed Technology. Heinemann, Berlin, Germany.

NRC. 1993. Nutrient Requirement of Fish. National Academy Press, Washington, DC, USA.

NRC. 2011. Nutrient requirements of fish and shrimp. National Academies Press, Washington D.C., USA.

Ogino C. 1980. Requirements of carp and rainbow trout for essential amino acids. Bull Jpn Soc Sci Fish 46: 171-174.

Polat A. 1999. The effects of methionine supplementation to soybean meal (SBM)-based diets on the growth and whole body carcass chemical composition of tilapia (T. zilli). Turk J Zool 23: 173-178.

Poston HA. 1986. Response of rainbow trout to source and level of supplemental dietary methionine. Comp Biochem Physiol 83: 739744

Ravi J, Devaraj KV. 1991. Quantitative essential amino acid requirements for growth of Catla catla (Hamilton). Aquaculture 96: 281-289.

Rumsey GL, Page JW, Scott ML. 1983. Methionine and cysteine requirements of rainbow trout. Progress Fish Cult 45: 139-143.

Santiago CB, Lovell RT. 1988. Amino acid requirements for growth of Nile tilapia. J Nutr 118: 1540-1546.

Snedecor GW, Cochran WG. 1968. Statistical Methods. 6th ed. Iowa State University Press, Ames, IA

Sokal RR, Rohlf FJ. 1981. Biometry. W.H. Freeman Company, NY.

Sveier H, Nordas H, Berge GE, Lied E. 2001. Dietary inclusion of crystalline d- and 1-methionine: effects on growth, feed and protein utilization, and digestibility in small and large Atlantic salmon. Aquac Nutr 7: 169-181.

Teshima S, Alam MS, Koshio S, Ishikawa M, Kanazawa A. 2002. Assessment of requirement values for essential amino acids in the prawn, Marsupenaeus japonicus. Aquacult Res 33: 395-402.

Walton MJ, Cowey CB, Andron JW. 1982. Methionine metabolism in rainbow trout fed diets of differing methionine and cysteine content. J Nutr 112: 1525-1535.

Yamashita K, Ashida K. 1969. Lysine metabolism in rats fed lysine-free diet. J Nutr 99: 267- 273.

Yousif RA, Abdullah OJ, Ahmed AM, Adam MI, Mohamed AFA, Idam OA. 2019. Effect of replacing fishmeal with water spinach (Ipomoea aquatica) on growth, feed conversion and carcass composition for Nile Tilapia fry (Oreochromis niloticus). J Aquat Sci Mar Biol 2 (4): 3-20.

Yousif RA, Hamed MAM, Dungos FA, Yagob GA. 2019. Effect of replacing fishmeal with baobab seed meal (Adansonia digitata) on growth, feed conversion and carcass composition for Nile Tilapia fry (Oreochromis niloticus). Egypt Acad J Biol Sci 11 (3): 97-105.

Zeitoun IH, Ullrey DE, Magee WT, Gill JL, Bergen WG. 1976 Quantifying nutrient requirements of fish. J Fish Res Board Can 33: $167-172$ 